\title{
Lack of $\mathrm{CB}_{1}$ receptor activity impairs serotonergic negative feedback
}

Ester Aso ${ }^{1}$, Thibault Renoir ${ }^{2}$, Guadalupe Mengod ${ }^{3}$, Catherine Ledent $^{4}$, Michel Hamon ${ }^{2}$, Rafael Maldonado ${ }^{5}$, Laurence Lanfumey ${ }^{2}$, Olga Valverde $^{1^{*}}$

${ }^{1}$ Grup de Recerca de Neurobiologia del Comportament (GRNC) and ${ }^{5}$ Laboratori de Neurofarmacologia, Departament de Ciències Experimentals i de la Salut, Universitat Pompeu Fabra, PRBB, Barcelona, Spain

${ }^{2}$ INSERM UMR 677, Faculté Médecine La Pitié-Salpêtrière, Université Pierre et Marie Curie-Paris VI, Paris, France

${ }^{3}$ Department of Neurochemistry, Institut d'Investigacions Biomèdiques de Barcelona, CSIC (IDIBAPS), Barcelona, Spain

${ }^{4}$ IRIBHM, Université Libre de Bruxelles, Brussels B-1070, Belgium

*Corresponding author:

Olga Valverde, Grup de Recerca de Neurobiologia del Comportament, Departament de Ciències Experimentals i de la Salut, Universitat Pompeu Fabra, PRBB, C/ Doctor Aiguader 88, 08003 Barcelona, Spain. Phone: +34-93-3160867; Fax: + 34-93-3161901; E-mail: olga.valverde@upf.edu

Abbreviations: 5-hydroxytryptamine or serotonin (5-HT), 5-hydroxytryptamine transporter (5-HTT), cannabinoid receptor $1\left(\mathrm{CB}_{1}\right)$, dorsal raphe nucleus $(\mathrm{DRN})$, prefrontal cortex (PFC), hypothalamic pituitary adrenal axis (HPA). 


\section{Abstract}

Serotonergic and endocannabinoid systems are important substrates for the control of emotional behavior and growing evidence show an involvement in the pathophysiology of mood disorders. In the present study, the absence of the activity of the $\mathrm{CB}_{1}$ cannabinoid receptor impaired serotonergic negative feedback in mice. Thus, in vivo microdialysis experiments revealed increased basal 5-HT extracellular levels and attenuated fluoxetine-induced increase of 5-HT extracellular levels in the prefrontal cortex of $\mathrm{CB}_{1}$ knockout compared to wild-type mice. These observations could be related to the significant reduction in the 5-HT transporter binding site density detected in frontal cortex and hippocampus of $\mathrm{CB}_{1}$ knockout mice. The lack of $\mathrm{CB}_{1}$ receptor also altered some 5-HT receptors related to the 5-HT feedback. Extracellular recordings in the dorsal raphe nucleus revealed that the genetic and pharmacological blockade of $\mathrm{CB}_{1}$ receptor induced a 5- $\mathrm{HT}_{1 \mathrm{~A}}$ autoreceptor functional desensitization. In situ hybridization studies showed a reduction in the expression of the $5-\mathrm{HT}_{2 \mathrm{C}}$ receptor within several brain areas related to the control of the emotional responses, such as the dorsal raphe nucleus, the nucleus accumbens and the paraventricular nucleus of the hypothalamus, whereas an overexpression was observed in the CA3 area of the ventral hippocampus. These results reveal that the lack of $\mathrm{CB}_{1}$ receptor induces a facilitation of the activity of serotonergic neurons in the dorsal raphe nucleus by altering different components of the 5-HT feedback as well as an increase in 5-HT extracellular levels in the prefrontal cortex in mice.

Keywords: 5-HT, $\mathrm{CB}_{1}$ cannabinoid receptor, 5-HTT, 5- $\mathrm{HT}_{1 \mathrm{~A}}, 5-\mathrm{HT}_{2 \mathrm{C}}$

Running title: 5-HT feedback in $\mathrm{CB}_{1} \mathrm{KO}$ mice 


\section{Introduction}

The serotonergic system has been related to the control of emotional responses and the impairment of serotonin (5-HT) neurotransmission has been classically associated to the pathophysiology of mood disorders. Thus, some pharmacological agents that increase 5HT synaptic levels exhibit antidepressant properties (Artigas et al, 2002; Nutt et al, 2002). 5-HT neurons are mainly located within the raphe nuclei. 5-HT is released from the terminals that project to multiple brain regions to regulate several behaviours, including cognition and mood. The removal of 5-HT from the synaptic cleft is carried out by a single protein, the 5-HT transporter (5-HTT). The 5-HTT determines the size and duration of the serotonergic responses, playing a key role in serotonergic neurotransmission (Lesch and Mössner, 2006). Up to 14 pre- and post-synaptic 5-HT receptors have been identified, which mediate 5-HT responses (Nichols and Nichols, 2008). 5-HT pre- and post-synaptic receptors also display a regulatory action on the serotonergic activity. Accordingly, the somatodendritic 5- $\mathrm{HT}_{1 \mathrm{~A}}$ autoreceptor negatively controls cell firing and impulse-dependent 5-HT release of serotonergic neurons whereas the axonal 5- $\mathrm{HT}_{1 \mathrm{~B}}$ receptor controls $5-\mathrm{HT}$ synthesis and release at terminal level (Barnes and Sharp, 1999). Similarly, some post-synaptic receptors such as 5-HT 1 , 5- $\mathrm{HT}_{2 \mathrm{~A}}$ and 5- $\mathrm{HT}_{2 \mathrm{C}}$ receptors, also participate in the inhibition of 5-HT neurons activity (Hajós et al, 1999; Boothman et al, 2003). Among all these post-synaptic receptors, growing attention has been addressed toward understanding the role of 5- $\mathrm{HT}_{2 \mathrm{C}}$ receptor in the regulation of emotional state beyond the involvement in 5-HT feedback regulation. This receptor plays an essential role in the 5-HT-induced hypothalamic pituitary adrenal (HPA) axis activation (Heisler et al, 2007) and also mediates the 
inhibition of dopaminergic system, a key component for hedonia and motivation (Dremencov et al, 2006).

Endocannabinoid system is one of the major neuromodulatory systems in the brain and previous studies revealed its contribution on maintaining the homeostasis of various states including mood and emotion (Valverde, 2005; Moreira and Lutz, 2008). In fact, the pharmacological and genetic blockade of the cannabinoid $\mathrm{CB}_{1}$ receptor induces a phenotypic state analogous to depression in experimental animals (Hill and Gorzalka, 2005; Aso et al, 2008). Therefore, $\mathrm{CB}_{1}$ knockout mice exhibit depressive-like symptoms such as reduced responsiveness to reward stimuli (Sanchís-Segura et al, 2004; Maldonado et al, 2006), altered neurovegetative functions (Cota et al, 2003), deficits in extinction of aversive memories (Marsicano et al, 2002) and higher anxiety levels and sensitivity to stress than control animals (Martín et al, 2002; Aso et al, 2008). The role of endocannabinoid system in regulating emotions and mood could be provided by the modulation of neurotransmitter release, including 5-HT, exerted by $\mathrm{CB}_{1}$ receptors (Tzavara et al, 2003; Szabo and Schlicker, 2005; Bambico et al, 2007). The interaction between 5-HT and endocannabinoid systems is also sustained by the fact that 5-HT is able to evoke endocannabinoid release (Parrish and Nichols, 2006; Best and Regehr, 2008). However, further investigations are needed to better understand the interaction between the endocannabinoid system and the different components of the serotonergic system in the modulation of mood and emotions. In this study, we therefore aimed to investigate the role of endocannabinoid system in the regulation of 5-HT neurotransmission by assessing the functionality of some serotonergic components involved in 5-HT feedback in the absence of $\mathrm{CB}_{1}$ receptor. 


\section{Materials and methods}

\section{Animals}

The experiments were carried out in male $\mathrm{CB}_{1}$ knockout mice and wild-type littermates 8-12 weeks old at the beginning of the experiments. The generation of mice lacking $\mathrm{CB}_{1}$ cannabinoid receptor was described previously (Ledent et al, 1999). In order to homogenize the genetic background of mice, the first generation heterozygous was bred for 30 generations on a $\mathrm{CD} 1$ background, with selection for the mutant $\mathrm{CB}_{1}$ gene at each generation. After the $30^{\text {th }}$ generation of backcross, heterozygote-heterozygote mating of $\mathrm{CB}_{1}$ knockout mice produced wild-type and knockout littermates for subsequent experiments. All animals used in a given experiment were matched for age and weight. Mice were housed five per cage in a temperature $\left(21 \pm 1^{\circ} \mathrm{C}\right)$ and humiditycontrolled $(55 \pm 10 \%)$ room with a 12:12-h light/dark cycle (light between 08:00 and 20:00 h) with food and water ad libitum. Animal procedures were conducted according to ethical guidelines (European Communities Council Directive 86/609/EEC) and approved by the Local Ethical Committee (PRBB).

\section{Drugs}

The selective 5-HT reuptake inhibitor (SSRI) fluoxetine hydrochloride was supplied by Sigma ${ }^{\circledR}$ Chemical Co (Madrid, Spain). Fluoxetine was dissolved in distilled water and injected intraperitoneally (i.p.) in a volume of $10 \mathrm{~mL} / \mathrm{kg}$ body weight. The $\mathrm{CB}_{1}$ receptor antagonist, rimonabant, was kindly provided by Sanofi-Aventis (Bagneux, France). Rimonabant was emulsified in two drops of Tween 80 and then suspended in saline for i.p. administration in a volume of $10 \mathrm{~mL} / \mathrm{kg}$ body weight. The $5-\mathrm{HT}_{1 \mathrm{~A}}$ receptor agonist ipsapirone was purchased by Bayer-Troponwerke (Cologne, Germany). 


\section{In vivo microdialysis procedure}

Mice were anesthetized with a ketamine/xylazine mixture $(0.2 \mathrm{~mL} / 10 \mathrm{~g}$ body weight i.p.) and placed in a stereotaxic apparatus with a flat skull (Paxinos and Franklin, 1997). A small hole was drilled on the skull and a $2 \mathrm{~mm}$ analytical probe (CMA/7/2 mm, CMA Microdialysis, Stockholm, Sweden) was implanted directly in the prefrontal cortex (PFC) (AP, $+2.1 \mathrm{~mm}$; ML, $\pm 0.5 \mathrm{~mm}$; DV,$-3.0 \mathrm{~mm}$ from bregma) and then fixed to the skull with dental cement, as described (Trigo et al, 2007). One day after probe implantation, animals were habituated to the experimental environment overnight. The following morning, a Ringer solution was pumped through the dialysis probe $(\mathrm{NaCl}$, $148 \mathrm{mM}$; KCl, $2.7 \mathrm{mM} ; \mathrm{CaCl}_{2}, 1.2 \mathrm{mM}$ and $\mathrm{MgCl}_{2}, 0.8 \mathrm{mM}, \mathrm{pH}$ 6.0) at a constant rate of $1 \mu \mathrm{L} / \mathrm{min}$. Five consecutive 18-min dialysis samples were collected for the determination of baseline 5-HT levels. Then, mice were injected with saline or fluoxetine (10 mg/kg, i.p.) and collection of samples was continued for $4 \mathrm{~h}$ following injection. Dialysates $(15 \mu \mathrm{L})$ were injected without any purification into a HPLC system that consisted of a pump linked to an automatic injector (Agilent 1100, Palo Alto, USA), a reverse-phase column (Zorbax SB C18, $3.5 \mu \mathrm{m}, 150 \times 4.6 \mathrm{~mm}$, Agilent Technologies, Palo Alto, USA) and a coulometric detector (Coulochem II, ESA, Chelmsford, USA) with a 5011A analytical cell. 5-HT was quantified as described (Trigo et al, 2007). Briefly, the first electrode was fixed at $+50 \mathrm{mV}$ and the second electrode at $+300 \mathrm{mV}$. The gain of the detector was set at $10 \mathrm{nA}$. The composition of the mobile phase was $50 \mathrm{mM}$ sodium acetate, $0.1 \mathrm{mM} \mathrm{Na}_{2}$ EDTA, $0.65 \mathrm{mM}$ octane sulfonic acid sodium salt and $24 \%(\mathrm{vol} / \mathrm{vol})$ methanol, $\mathrm{pH} 5.0$. The flow rate was set at 0.8 $\mathrm{mL} / \mathrm{min}$ and the sensitivity of the assay for $5-\mathrm{HT}$ was $0.3 \mathrm{pg} / 15 \mu \mathrm{L}$. Percentage of 5-HT concentrations after either fluoxetine or saline challenge respect to basal concentrations 
were converted to area under the curve (AUC) using a standard trapezoid method (Gibaldi and Perrier, 1975). The following equation was used: $A U C=\left[0.5 *\left(B+C_{1}\right) * d\right.$ $\left.\left.+0.5^{*}\left(\mathrm{C}_{1}+\mathrm{C}_{2}\right) * \mathrm{~d}+0.5^{*}\left(\mathrm{C}_{2}+\mathrm{C}_{3}\right) * \mathrm{~d}+\ldots 0.5^{*}\left(\mathrm{C}_{\mathrm{n}-1}+\mathrm{C}_{\mathrm{n}}\right) * \mathrm{~d}\right)\right]$, where $\mathrm{B}$ is the average basal value, $C_{1}$ to $C_{n}$ are values during drug challenge, and $d$ is the duration of the sample (18 min in this case). At the end of the experiments, animals were sacrificed, and brains were quickly removed and stored at $-80^{\circ} \mathrm{C}$. To check the position of the probe, brains were cut using a cryostat in $20 \mu \mathrm{m}$ serial coronal sections, which were then processed with Cresyl Violet and observed under a microscope. Only those animals with correct probe placements were used in the study.

\section{$\left[{ }^{3} \mathrm{H}\right]$ Citalopram binding onto brain membranes}

Dissected tissues (anterior raphe area, hippocampus, striatum and frontal cortex) were homogenized in $40 \mathrm{vol}(\mathrm{w} / \mathrm{v})$ of ice-cold Tris-salt buffer $(50 \mathrm{mM}$ Tris- $\mathrm{HCl}, 120 \mathrm{mM}$ $\mathrm{NaCl}, 5 \mathrm{mM} \mathrm{KCl}, \mathrm{pH}$ 7.4) using a Polytron. Homogenates were centrifuged at 40,000 $\mathrm{g}$ for $20 \mathrm{~min}$, the pellets were suspended in $40 \mathrm{vol}$ of the same buffer and incubated at $37^{\circ} \mathrm{C}$ for $10 \mathrm{~min}$ to remove endogenous 5 -HT. The membranes were spun down at $40,000 \mathrm{~g}$ for $20 \mathrm{~min}$ and washed three times by suspension/centrifugation as before. The final pellet was suspended in 10 vol of the same buffer and $25 \mu \mathrm{L}$ aliquots were mixed with $225 \mu \mathrm{L}$ of fresh Tris-salt buffer, $\mathrm{pH} 7.4$, containing $\left[{ }^{3} \mathrm{H}\right]$ citalopram $(83.0 \mathrm{Ci} / \mathrm{mmol}$; $2 \mathrm{nM}$ final concentration) in an Optiplate 96-well apparatus (Perkin Elmer, Wellesley, MA) for $1 \mathrm{~h}$ incubation at room temperature. Nonspecific binding was determined in the presence of $10 \mu \mathrm{M}$ fluoxetine. After the incubation, the unifilter GF/B plate was drained with a FilterMate harvester (Perkin Elmer) and each well was washed three times with $500 \mu \mathrm{L}$ of ice-cold buffer. Microscint-40 scintillation cocktail $(30 \mu \mathrm{L})$ was added to each well of the plate, and radioactivity was counted using a TopCount scintillation 
counter (Perkin Elmer). The specific binding (expressed as $\mathrm{cpm} / 10 \mu \mathrm{g}$ protein) was obtained by subtracting non-specific binding from total binding. Proteins were quantified using the method of Lowry et al (1951) with bovine serum albumin as standard.

\section{Electrophysiological experiments}

Immediately after removal from the skull, brains were immersed in an ice-cold artificial cerebrospinal fluid (aCSF) ( $\mathrm{NaCl} 126 \mathrm{mM}, \mathrm{KCl} 3.5 \mathrm{mM}, \mathrm{NaH}_{2} \mathrm{PO}_{4} 1.2 \mathrm{mM}, \mathrm{MgCl}_{2} 1.3$ $\mathrm{mM}, \mathrm{CaCl}_{2} 2.0 \mathrm{mM}, \mathrm{NaHCO}_{3} 25 \mathrm{mM}$, D-glucose $11 \mathrm{mM}$ ), continuously bubbled with carbogen $\left(95 \% \mathrm{O}_{2}, 5 \% \mathrm{CO}_{2}\right)$ to maintain $\mathrm{pH}$ value at 7.3. A block of tissue containing the dorsal raphe nucleus (DRN) was cut into sections (400 $\mu \mathrm{m}$ thick) in the same aCSF using a vibratome. Brainstem slices were immediately immersed in oxygenated aCSF at room temperature $\left(22^{\circ} \mathrm{C}\right)$. A single slice was then placed on a nylon mesh, completely submerged in the recording chamber and continuously superfused with oxygenated aCSF $\left(34{ }^{\circ} \mathrm{C}\right)$ at a constant flow rate of $2-3 \mathrm{~mL} / \mathrm{min}$. Extracellular recordings of the firing of DRN serotonergic neurons were made using glass microelectrodes filled with 2 $\mathrm{M} \mathrm{NaCl}(12-15 \mathrm{M} \Omega)$. Cells were identified as 5-HT neurons according to previously described criteria (Lanfumey et al, 1999). Firing was evoked in the otherwise silent neurons by adding the $\alpha 1$ adrenoceptor agonist phenylephrine $(3 \mu \mathrm{M})$ into the superfusing aCSF (VanderMaelen and Aghajanian 1983). Electrical signals were fed into a high-input impedance amplifier (VF 180, BioLogic, Claix, France), an oscilloscope and an electronic ratemeter triggered by individual action potentials, connected to an A/D converter and a personal computer. Using dedicated software, the integrated firing rate was recorded, computed, and displayed on a chart recorder as consecutive 10-s samples. Baseline activity was recorded for at least $10 \mathrm{~min}$ prior to 
perfusion of drugs into the chamber, via a three-way tap system. Because complete exchange of fluids occurred within 2 min following the arrival of a new solution into the chamber, the duration of each drug application was $3 \mathrm{~min}$. The effects of the $5-\mathrm{HT}_{1 \mathrm{~A}}$ receptor agonist ipsapirone were evaluated by comparing the mean discharge frequency during the 2 min prior to its application with that recorded at the peak action of the drug, i.e. 2-3 min after its removal from the perfusing aCSF. Data are expressed as percentages of the baseline firing rates.

\section{Pharmacological treatment}

The $\mathrm{CB}_{1}$ receptor antagonist, rimonabant, and its vehicle were administered i.p. (3 $\mathrm{mg} / \mathrm{kg}$ ) once a day (6:00 p.m.) during 2 weeks to two different groups of wild-type mice. Animals were sacrificed and brains removed for the electrophysiological experiments $18 \mathrm{~h}$ after the last rimonabant injection.

\section{In situ hybridization}

The protocols for in situ hybridization were based on previously described procedures (López-Giménez et al, 2002; Serrats et al, 2005). Briefly, an oligonucleotide complementary to $1100-1147$ bases of the rat 5- $\mathrm{HT}_{2 \mathrm{C}}$ receptor cDNA (GenBank acc. no. U35315) was labeled at its 3'-end with terminal deoxynucleotidyltransferase (TdT, Oncogene Research Products, San Diego, CA, USA) and $\left[{ }^{33} \mathrm{P}\right] \alpha-\mathrm{dATP}\left(3000 \mathrm{Ci} \mathrm{mmol}^{-}\right.$ 1, New England Nuclear, Boston, MA, USA). Labeled probes were purified through ProbeQuant G-50 microcolumns (GE Healthcare, Little Chalfont, UK). The specificity of the probe has been previously established and published elsewhere (Pompeiano et al. 1994) 
Frozen tissue sections were brought to room temperature, air-dried and fixed in $4 \%$ paraformaldehyde in phosphate buffered saline (PBS: $8 \mathrm{mM} \mathrm{Na}_{2} \mathrm{HPO}_{4}, 1.4 \mathrm{mM}$ $\mathrm{KH}_{2} \mathrm{PO}_{4}, 136 \mathrm{mM} \mathrm{NaCl}, 2.6 \mathrm{mM} \mathrm{KCl}$ ), washed once in 3xPBS, twice in 1xPBS, $5 \mathrm{~min}$ each, and incubated in a freshly prepared solution of predigested pronase (Calbiochem, San Diego, USA) at a final concentration of $12 \mathrm{U} / \mathrm{mL}$ in $50 \mathrm{mM}$ Tris- $\mathrm{HCl} \mathrm{pH} 7.5$ and 5 $\mathrm{mM}$ EDTA for $2 \mathrm{~min}$ at room temperature. The enzymatic activity was stopped by immersion for $30 \mathrm{~s}$ in $2 \mathrm{mg} / \mathrm{mL}$ glycine in PBS. Tissues were finally rinsed in PBS and dehydrated. The radioactively labeled probe $(1.5 \mathrm{nM})$ was dissolved in the hybridization buffer $(50 \%$ formamide, 4xSSC, 1x Denhardt's solution, 1\% sarkosyl, 10\% dextran sulfate, $20 \mathrm{mM}$ phosphate buffer, $\mathrm{pH} 7,250 \mu \mathrm{g} / \mathrm{ml}$ yeast tRNA and $500 \mu \mathrm{g} / \mathrm{ml}$ salmon sperm DNA), Tissue sections were covered with hybridization buffer, overlaid with Nescofilm coverslips (Bando Chemical Ind., Kobe, Japan) and incubated overnight at $42{ }^{\circ} \mathrm{C}$ in humid boxes. The sections were then washed in a buffer, in $600 \mathrm{mM} \mathrm{NaCl}, 10$ $\mathrm{mM}$ Tris- $\mathrm{HCl}, \mathrm{pH} 7.5$, and $1 \mathrm{mM}$ EDTA at $60^{\circ} \mathrm{C}$. For film autoradiography, hybridized sections were exposed to Biomax-MR (Kodak) films for $66 \mathrm{~h}$ at $-70^{\circ} \mathrm{C}$ with intensifying screens. Film autoradiograms were scanned with the GS-800 Calibrated Densitometer (Bio-Rad Laboratories, Hercules, USA). The average density of $5-\mathrm{HT}_{2 \mathrm{C}}$ mRNA in different brain regions was evaluated semiquantitatively with Quantity One 4.6.3 software (Bio-Rad Laboratories, Hercules, USA).

\section{Statistical analyses}

All data are given as means \pm SEM. In vivo microdialysis data were analyzed using three-way ANOVA with treatment (saline and fluoxetine) and genotype (wild-type and $\mathrm{CB}_{1}$ knockout) as between-subjects factors and time after fluoxetine injection as withinsubjects factor and subsequent two-way ANOVA with genotype and treatment as 
between-subjects factors, followed by one-way ANOVA, when required. AUC values were compared by using a between-subjects two-way ANOVA (genotype and treatment), followed by one-way ANOVA for individual differences when required. Extracellular recordings were analyzed by between-subjects two-way ANOVA (ipsapirone concentration and genotype/chronic treatment) followed by Bonferroni's post hoc $t$ test. Nonlinear regression was carried out using Prism 4.0 software (GraphPad Software Inc., San Diego, CA, USA) for the calculation of $\mathrm{EC}_{50}$ values of the drugs. Finally, 5-HTT biding and $5-\mathrm{HT}_{2 \mathrm{C}}$ receptor expression quantification were analyzed by one-way ANOVA (genotype). In all the experiments, the significance level was set at $\mathrm{p}<0.05$. 


\section{Results}

\section{5-HT extracellular levels in the PFC under basal conditions and after acute fluoxetine administration}

In vivo microdialysis procedure revealed a significant increase of basal 5-HT extracellular levels in the PFC of $\mathrm{CB}_{1}$ knockout compared to wild-type mice $\left(F_{(1,50)}=\right.$ 4.225, $\mathrm{p}<0.05$ ) (Fig 1A). Consequently, the further 5-HT extracellular levels measure in response to fluoxetine acute administration was expressed as the percentage respect to the basal values for each genotype.

Fluoxetine $(10 \mathrm{mg} / \mathrm{kg}$, i.p.) induced an increase in 5-HT extracellular levels in the PFC in both genotypes. However, the $\mathrm{CB}_{1}$ knockout mice response was lower than wild-type animals (Fig 1B). Three-way ANOVA showed a significant main effect of time $\left(F_{(11}\right.$, $\left.{ }_{132)}=1.975, \mathrm{p}<0.05\right)$ and treatment $\left(F_{(1,12)}=26.668, \mathrm{p}<0.001\right)$, without genotype effect after fluoxetine or saline injection. A significant interaction between time and treatment $\left(F_{(11,132)}=2.102, \mathrm{p}<0.05\right)$ was revealed, but no other two- or three-way interactions between factors were observed. Two-way ANOVA (genotype and treatment) indicated a significant genotype effect $18 \mathrm{~min}$ and $144 \mathrm{~min}$ after fluoxetine or saline administration $\left(F_{(1,22)}=4.808, \mathrm{p}<0.05 ; F_{(1,22)}=4.376, \mathrm{p}<0.05\right.$, respectively $)$ and treatment effect $36 \min \left(F_{(1,21)}=15.071, \mathrm{p}<0.001\right), 54 \min \left(F_{(1,22)}=26.213, \mathrm{p}<\right.$ 0.001), $72 \min \left(F_{(1,20)}=36.753, \mathrm{p}<0.001\right), 90 \min \left(F_{(1,23)}=41.090, \mathrm{p}<0.001\right), 108$ $\min \left(F_{(1,21)}=27.412, \mathrm{p}<0.001\right), 126 \min \left(F_{(1,19)}=25.518, \mathrm{p}<0.001\right), 144 \min \left(F_{(1,22)}\right.$ $=28.262, \mathrm{p}<0.001), 162 \min \left(F_{(1,21)}=36.343, \mathrm{p}<0.001\right), 180 \min \left(F_{(1,20)}=38.684, \mathrm{p}\right.$ $<0.001), 198 \min \left(F_{(1,22)}=32.420, \mathrm{p}<0.001\right)$ and $216 \min \left(F_{(1,20)}=24.619, \mathrm{p}<0.001\right)$ after fluoxetine or saline administration. Significant interaction between both genotype and treatment was observed $108 \mathrm{~min}$ and $144 \mathrm{~min}$ after fluoxetine or saline 
administration $\left(F_{(1,21)}=7.545, \mathrm{p}<0.05 ; F_{(1,22)}=4.660, \mathrm{p}<0.05\right.$, respectively $)$. Subsequent one-way ANOVA (genotype) showed a reduction in the percentage of increase of the 5-HT extracellular levels in $\mathrm{CB}_{1}$ knockout mice respect to wild-type littermates $108 \mathrm{~min}, 126 \mathrm{~min}$ and $144 \mathrm{~min}$ after the fluoxetine administration $\left(F_{(1,14)}=\right.$ 10.877, $\mathrm{p}<0.01 ; F_{(1,13)}=8.885, \mathrm{p}<0.05 ; F_{(1,14)}=8.052, \mathrm{p}<0.05$, respectively). Figure $1 \mathrm{C}$ represents the AUC values for percentage of 5-HT extracellular levels after fluoxetine or saline administration respect to basal values. Two-way ANOVA revealed treatment effect $\left(F_{(1,23)}=64.719, \mathrm{p}<0.001\right)$, no genotype effect, and a significant interaction between these two factors $\left(F_{(1,23)}=7.270, \mathrm{p}<0.05\right)$. Subsequent one-way ANOVA (treatment) revealed a significant effect of fluoxetine in wild-type mice $\left(F_{(1,12)}\right.$ $=41.417, \mathrm{p}<0.001)$ and in $\mathrm{CB}_{1}$ knockout mice $\left(F_{(1,11)}=27.998, \mathrm{p}<0.001\right)$. Comparisons between genotypes indicated no differences after saline treatment but lower AUC value in mutant than in wild-type mice after fluoxetine treatment $\left(F_{(1,14)}=\right.$ $7.575, \mathrm{p}<0.05)$.

\section{Decreased 5-HTT binding site density in frontal cortex and hippocampus of $\mathbf{C B}_{1}$}

\section{knockout mice}

One-way ANOVA revealed a significant decrease of the 5-HTT binding site density in the frontal cortex $\left(F_{(1,19)}=5.960, \mathrm{p}<0.05\right)$ and in the hippocampus $\left(F_{(1,19)}=18.906, \mathrm{p}\right.$ $<0.001)$ of $\mathrm{CB}_{1}$ knockout compared to wild-type. No differences between genotypes were observed either in the striatum or in the anterior raphe (Fig 2).

$5-H_{1 A}$ autoreceptor functional desensitization in the absence of $\mathrm{CB}_{1}$ receptor activity 
Extracellular recordings were made from serotonergic neurons of the DRN in slices preparations of brains from $\mathrm{CB}_{1}$ knockout and wild-type mice. Two-way ANOVA revealed a significant ipsapirone concentration-dependent inhibition $\left(F_{(7,140)}=119.980\right.$, $\mathrm{p}<0.001)$ and a significant genotype effect $\left(F_{(1,140)}=7.120, \mathrm{p}<0.01\right)$ on the firing of serotonergic neurons, without interaction between ipsapirone and genotype (Fig 3A). However, Bonferroni's post hoc $t$ test indicated a significant difference between genotypes at the ipsapirone $60 \mathrm{nM}$ and $100 \mathrm{nM}$ concentrations $(\mathrm{p}<0.05$, respectively). Indeed, the concentration-response curve of ipsapirone in $\mathrm{CB}_{1}$ mutants was shifted to the right as compared with that for wild-type mice (Fig 3B). Thus, the $\mathrm{EC}_{50}$ value of ipsapirone was higher in $\mathrm{CB}_{1}$ knockout mice $\left(\mathrm{EC}_{50}: 58.04 \mathrm{nM} ; 95 \% \mathrm{CI}: 50.66-66.50\right.$ $\mathrm{nM})$ than in wild-type mice $\left(\mathrm{EC}_{50}: 37.36 \mathrm{nM} ; 95 \% \mathrm{CI}: 33.39-41.79 \mathrm{nM}\right)$, indicating a functional desensitization of the 5- $\mathrm{HT}_{1 \mathrm{~A}}$ autoreceptor in the $\mathrm{DRN}$ of $\mathrm{CB}_{1}$ knockout mice.

The electrophysiological data obtained from the $\mathrm{CB}_{1}$ knockout mice were in the same line than the results found by the pharmacological blockade of the $\mathrm{CB}_{1}$ receptor with a chronic treatment with rimonabant (3mg/kg/day, 14 days) (Fig 4A and 4B). Two-way ANOVA revealed a significant ipsapirone concentration-dependent inhibition $\left(F_{(6,96)}=\right.$ 85.250, $\mathrm{p}<0.001)$, a significant effect of rimonabant treatment $\left(F_{(1,96)}=12.610, \mathrm{p}<\right.$ $0.001)$ and a significant interaction between ipsapirone and rimonabant $\left(F_{(6,76)}=2.960\right.$, $\mathrm{p}<0.05$ ) on the firing of serotonergic neurons (Fig 4A). Bonferroni's post hoc $t$ test indicated a significant difference between vehicle- and rimonabant-treated mice at the ipsapirone $60 \mathrm{nM}$ concentration $(\mathrm{p}<0.001)$. Indeed, the concentration-response curve of ipsapirone in rimonabant chronically treated animals was significantly shifted to the right as compared to vehicle treated mice (Fig 4B). Thus, the $\mathrm{EC}_{50}$ value of ipsapirone was higher in rimonabant-treated $\left(\mathrm{EC}_{50}: 53.99 \mathrm{nM} ; 95 \% \mathrm{CI}: 43.88-66.45 \mathrm{nM}\right)$ than in 
vehicle-treated mice $\left(\mathrm{EC}_{50}: 30.13 \mathrm{nM} ; 95 \%\right.$ CI: 23.16 - $\left.34.76 \mathrm{nM}\right)$, confirming a functional desensitization of the $5-\mathrm{HT}_{1 \mathrm{~A}}$ autoreceptor in the $\mathrm{DRN}$ in the absence of $\mathrm{CB}_{1}$ receptor activity.

\section{Altered 5-HT $2 \mathrm{C}$ receptor expression in $\mathrm{CB}_{1}$ knockout mice}

In situ hybridization experiments were carried out to study the distribution of the mRNA coding for 5- $\mathrm{HT}_{2 \mathrm{C}}$ receptor in the brain of $\mathrm{CB}_{1}$ receptor knockout and wild-type mice (Fig 5). Brain sections from both genotypes were included in the same hybridization experiment, and regions to be compared from both groups were exposed to the same $\beta$-max film. After the appropriate exposure time, optical densities over the regions of interest were determined for both groups and the values statistically analyzed by one-way ANOVA. A significant decrease in the expression of 5- $\mathrm{HT}_{2 \mathrm{C}}$ receptor was observed in most of the brain areas examined, including the nucleus accumbens (NAcc) $\left(F_{(1,9)}=9.069, \mathrm{p}<0.05\right)$, caudate putamen nucleus $(\mathrm{CPu})\left(F_{(1,10)}=6.408, \mathrm{p}<0.05\right)$, piriform cortex (Pir) $\left(F_{(1,10)}=17.264, \mathrm{p}<0.01\right)$, paraventricular nucleus of the hypothalamus $(\mathrm{PVN})\left(F_{(1,9)}=7.078, \mathrm{p}<0.05\right)$, retrosplenial granular cortex $(\mathrm{RSG})\left(F_{(1,}\right.$ 10) $=12.371, \mathrm{p}<0.01)$, choroid plexus $(\mathrm{ChP})\left(F_{(1,10)}=59.036, \mathrm{p}<0.001\right)$, habenula $(\mathrm{Hab})\left(F_{(1,9)}=6.855, \mathrm{p}<0.05\right)$ and $\operatorname{DRN}\left(F_{(1,10)}=5.682, \mathrm{p}<0.05\right)$. In contrast, a significant increase in the $5-\mathrm{HT}_{2 \mathrm{C}}$ receptor expression was observed in the CA3 area of the ventral hippocampus $\left(F_{(1,10)}=9.959, \mathrm{p}<0.05\right)$. No significant differences were observed in the PFC, lateral amygdala (Amy) or periaqueductal gray (PAG) brain areas. 


\section{Discussion}

The present study demonstrates that endocannabinoid system through $\mathrm{CB}_{1}$ receptor modulates the activity of the serotonergic system. In particular, mice lacking $\mathrm{CB}_{1}$ receptor exhibited increased 5-HT extracellular levels in the PFC that could be related to alterations of components involved in 5-HT negative feedback, such as 5-HTT, 5$\mathrm{HT}_{1 \mathrm{~A}}$ and $5-\mathrm{HT}_{2 \mathrm{C}}$ receptors.

In vivo microdialysis experiments demonstrated that $\mathrm{CB}_{1}$ knockout mice display a slight elevation in the basal extracellular 5-HT levels in the PFC. Our observation is in agreement with the moderately increased 5-HT efflux reported in the rat frontal cortex after the administration of the $\mathrm{CB}_{1}$ antagonist rimonabant (Tzavara et al, 2003). However, the peripheral administration of fluoxetine resulted on lower increase of 5-HT extracellular levels in the $\mathrm{PFC}$ of the $\mathrm{CB}_{1}$ knockout mice compared to wild-type animals, demonstrating that the blockade of $\mathrm{CB}_{1}$ receptor activity deregulates serotonergic function. In order to raise this issue, we analysed some of the most important mechanisms that control serotonergic feedback in the absence of $\mathrm{CB}_{1}$ receptor activity.

5-HTT mediates the 5-HT reuptake from the synaptic terminal and determines the size and duration of the serotonergic responses (Lesch and Mössner, 2006). Radioligand binding approaches revealed that $\mathrm{CB}_{1}$ knockout mice exhibited a significantly lower 5HTT binding site density in the frontal cortex and the hippocampus than wild-type mice. This finding could explain in part the decreased response to the fluoxetine treatment observed in mutants in the in vivo microdialysis experiments, given that 5HTT is the target for the 5-HT reuptake-inhibiting antidepressant compounds such as fluoxetine. In addition, our observation also supports the increased basal 5-HT 
extracellular levels in the PFC as seems to indicate a reduction in the 5-HT clearance of the synaptic cleft in the absence of $\mathrm{CB}_{1}$ receptor activity. However, the use of a method such as the no-net-flux technique should be used to confirm a possible reduction of the 5-HT clearance in vivo (Shippenberg et al, 1999).

The activity of the somatodendritic $5-\mathrm{HT}_{1 \mathrm{~A}}$ autoreceptor, which negatively controls the firing rate of serotonergic neurons located in the DRN (Barnes and Sharp, 1999), was evaluated by using an in vitro electrophysiological approach. Extracellular recordings were performed in brain slices containing the DRN in the presence of increasing concentration of 5- $\mathrm{HT}_{1 \mathrm{~A}}$ receptor agonist ipsapirone. Ipsapirone concentration required to obtain a reduction in the serotonergic firing was significantly higher in the $\mathrm{CB}_{1}$ knockout mice than in wild-type mice, revealing a functional desensitization of $5-\mathrm{HT}_{1 \mathrm{~A}}$ autoreceptors in those mutants. Similar results were obtained in wild-type animals receiving a chronic treatment with the $\mathrm{CB}_{1}$ receptor antagonist rimonabant. The functional desensitization of the $5-\mathrm{HT}_{1 \mathrm{~A}}$ autoreceptor demonstrated in this study through a genetic and a pharmacological blockade of $\mathrm{CB}_{1}$ receptor is supported by the reduced hypothermia induced by the $5-\mathrm{HT}_{1 \mathrm{~A}}$ receptor agonist $8-\mathrm{OH}-\mathrm{DPAT}$ in $\mathrm{CB}_{1}$ knockout mice previously reported (Mato et al, 2007). This finding could be linked to the increased basal 5-HT extracellular levels observed in the PFC of mutant animals since 5- $\mathrm{HT}_{1 \mathrm{~A}}$ receptors were less efficient in inhibiting 5-HT neurons activity. In contrast to this assumption, the genetic deletion of the $5-\mathrm{HT}_{1 \mathrm{~A}}$ receptors has not been reported to modify basal 5-HT extracellular levels in different brain areas including PFC (He et al, 2001; Guilloux et al, 2006).

Although 5-HTT and 5-HT autoreceptors exert a clear-cut role within the regulation of 5-HT system, emerging findings indicate additional complexity of 5-HT feedback control involving post-synaptic 5-HT receptors (Sharp et al, 2007). Among all the post- 
synaptic receptors, we focused on $5-\mathrm{HT}_{2 \mathrm{C}}$ receptor because of its participation on the regulation of emotional state beyond the involvement in 5-HT feedback regulation. This receptor plays an essential role in the 5-HT-induced HPA axis activation (Heisler et al, 2007) and also mediates the inhibition of dopaminergic system, a key component for hedonia and motivation (Dremencov et al, 2006). Then, we assessed the expression of 5- $\mathrm{HT}_{2 \mathrm{C}}$ receptors mRNA in different brain areas related to motivation, HPA axis and 5HT feedback regulation by in situ hybridization. $\mathrm{CB}_{1}$ knockout mice exhibited a reduction in the expression of the 5- $\mathrm{HT}_{2 \mathrm{C}}$ receptor in the DRN, the NAcc and the PVN, among other brain areas. Interestingly, $5-\mathrm{HT}_{2 \mathrm{C}}$ receptor was overexpressed in the $\mathrm{CA} 3$ area of the ventral hippocampus of $\mathrm{CB}_{1}$ knockout mice, suggesting a differential role of this receptor in this discrete brain area, which would deserve additional attention. The decreased expression of $5-\mathrm{HT}_{2 \mathrm{C}}$ receptor in the $\mathrm{DRN}$ of $\mathrm{CB}_{1}$ mutant mice could lead to a reduction in the inhibitory effect exerted by $5-\mathrm{HT}_{2 \mathrm{C}}$ receptor on $5-\mathrm{HT}$ neurons through GABAergic mechanism (Boothman et al, 2006). This assumption could support the increased 5-HT extracellular levels in the brain areas receiving projections from the $\mathrm{DRN}$ in $\mathrm{CB}_{1}$ knockout mice revealed by the present results. Nevertheless, the genetic or pharmacological blockade of $5-\mathrm{HT}_{2 \mathrm{C}}$ receptors seems not to affect the basal 5-HT extracellular levels (Cremers et al, 2004). In a similar way than in DRN, the decreased levels of 5-HT $2 \mathrm{C}$ mRNA in mutant mice within the NAcc and the PVN could indicate a diminished capacity of this receptor to inhibit dopamine activity (Dremencov et al, 2006) and to stimulate corticotrophin-releasing factor release (Heisler et al, 2007), respectively.

In conclusion, the present results indicate that the lack of $\mathrm{CB}_{1}$ receptor activity alters 5$\mathrm{HT}_{1 \mathrm{~A}}$ and $5-\mathrm{HT}_{2 \mathrm{C}}$ receptors as well as the 5-HTT density, leading to increased 5-HT extracellular levels as we summarize in Fig 6. Classically, mood disorders have been 
associated to reduced 5-HT activity basing on the mechanism of action of antidepressant compounds (Charney, 1998; Artigas et al, 2002). In contrast to what we could expect considering this classical hypothesis, the genetic and pharmacological blockade of the $\mathrm{CB}_{1}$ receptor induces a depressive-like phenotype (Hill and Gorzalka, 2005; Mangieri and Piomelli, 2007; Aso et al, 2008). From our point of view, this apparent controversy points out that the chronic absence of $\mathrm{CB}_{1}$ receptor could impair mechanisms controlling emotional homeostasis beyond 5-HT neurotransmission. Thus, the absence of $\mathrm{CB}_{1}$ receptor alters the HPA axis activity (Cota, 2008) and neural plasticity that are likely to contribute to emotional disturbances (Berton and Nestler, 2006). In this sense, we have previously demonstrated that the enhanced glucocorticoids levels in $\mathrm{CB}_{1}$ knockout mice could produce hippocampal BDNF impairment, which plays a crucial role on the increased despair behavior exhibited by those mutants (Aso et al, 2008). The alterations on 5-HT neurotransmission reported in the present study are supposed to be a substrate for counteracting the stress-induced emotional impairments in mice lacking $\mathrm{CB}_{1}$ receptor, since similar alterations have been described after antidepressant treatments (Le Poul et al, 2000; Lanfumey et al, 2000; Gould et al, 2006). Nevertheless, it has been reported an altered post-synaptic serotonergic signalling in $\mathrm{CB}_{1}$ mutant mice (Mato et al, 2007) that could lead to a reduction in the efficacy of 5-HT for ameliorating their depressive-like phenotype. As a result, the deregulation of glucocorticoid release and the deficiency of neurotrophic mechanisms could prevail upon the alterations on 5HT neurotransmission, leading to the depressive-like phenotype exhibited by $\mathrm{CB}_{1}$ mutant mice. However, we can not rule out the possibility that the reduced 5-HTT levels and the 5-HT $\mathrm{H}_{1 \mathrm{~A}}$ desensitization reported in the present study could be per se a possible substrate for the depressive-like phenotype exhibited by $\mathrm{CB}_{1}$ knockout mice. Thus, an impaired 5-HTT function (Caspi et al, 2003; Olivier et al, 2008) and a 5-HT $1 \mathrm{~A}$ 
desensitization (Lesch et al, 1990; Cowen et al, 1994; Bambico et al, 2009) have been associated to an increased vulnerability to depressive symptoms in animal models as well as in humans.

In summary, we can conclude that the lack of $\mathrm{CB}_{1}$ receptor induces an increase in 5-HT extracellular levels by modulating different components of the serotonergic feedback. These alterations could account for the depressive-like phenotype exhibited by $\mathrm{CB}_{1}$ knockout mice. 


\section{Acknowledgements:}

We thank Dulce Real, Marta Linares and Rocío Martín for their excellent technical support, Arnau Busquets for his help on the in situ hybridization experiments and Dr Patricia Robledo for kind advices about in vivo microdialysis procedure. This study has been supported by grants from the UE Sixth Framework Programme (NEWMOOD, LSHM-CT-2004-503474 to RM and LL), Spanish Ministry of Education \& Science (SAF 2007/60249 to OV, BES-2005-8265 fellowship to EA) and Spanish Ministry of Health (ISCIII-RD/06/0001/1001/ and PNSD Conv-2006 to OV). 


\section{References}

Artigas F., Nutt D.J., Shelton R. (2002) Mechanism of action of antidepressants. Psychopharmacol Bull 36:123-132.

Aso E., Ozaita A., Valdizán E.M., Ledent C., Pazos A., Maldonado R., Valverde O. (2008) BDNF impairment in the hippocampus is related to enhanced despair behavior in $\mathrm{CB}_{1}$ knockout mice. J Neurochem 105:565-572.

Bambico F.R., Katz N., Debonnel G., Gobbi G. (2007) Cannabinoids elicit antidepressant-like behavior and activate serotonergic neurons through the medial prefrontal cortex. J Neurosci 27:11700-11711.

Bambico F.R., Nguyen N.T., Gobbi G. (2009) Decline in serotonergic firing activity and desensitization of $5-\mathrm{HT}_{1 \mathrm{~A}}$ autoreceptors after chronic unpredictable stress. Eur Neuropsychopharmacol 19:215-228.

Barnes N.M., Sharp T. (1999) A review of central 5-HT receptors and their function. Neuropharmacology 38:1083-1152.

Berton O., Nestler E.J. (2006) New approaches to antidepressant drug discovery: beyond monoamines. Nat Rev Neurosci 7:137-151.

Best A.R., Regehr W.G. (2008) Serotonin evokes endocannabinoid release and retrogradely suppresses excitatory synapses. J Neurosci 28:6508-6515.

Boothman L.J., Allers K.A., Rasmussen K., Sharp T. (2003) Evidence that central 5$\mathrm{HT}_{2 \mathrm{~A}}$ and 5- $\mathrm{HT}_{2 \mathrm{~B} / \mathrm{C}}$ receptors regulate 5-HT cell firing in the dorsal raphe nucleus of the anaesthetised rat. Br J Pharmacol 139:998-1004.

Boothman L., Raley J., Denk F., Hirani E., Sharp T. (2006) In vivo evidence that 5$\mathrm{HT}_{(2 \mathrm{C})}$ receptors inhibit 5-HT neuronal activity via a GABAergic mechanism. $\mathrm{Br} J$ Pharmacol 149:861-869. 
Caspi A., Sugden K., Moffitt T.E., Taylor A., Craig I.W., Harrington H., McClay J., Mill J., Martin J., Braithwaite A., Poulton R. (2003) Influence of life stress on depression: moderation by a polymorphism in the 5-HTT gene. Science 301:386-389.

Charney D.S. (1998) Monoamine dysfunction and the pathophysiology and treatment of depression. J Clin Psychiatry 59:11-14.

Cota D., Marsicano G., Tschöp M., Grübler Y., Flachskamm C., Schubert M., Auer D., Yassouridis A., Thöne-Reineke C., Ortmann S., Tomassoni F., Cervino C., Nisoli E., Linthorst A.C., Pasquali R., Lutz B., Stalla G.K., Pagotto U. (2003) The endogenous cannabinoid system affects energy balance via central orexigenic drive and peripheral lipogenesis. J Clin Invest 112:423-431.

Cota D. (2008) The role of the endocannabinoid system in the regulation of hypothalamic-pituitary-adrenal axis activity. J Neuroendocrinol 20, Suppl 1:35-38.

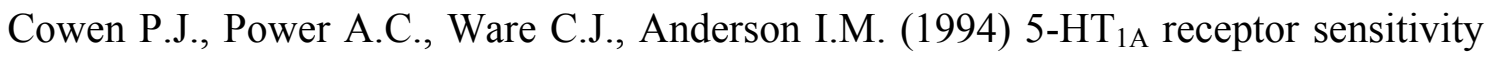
in major depression. A neuroendocrine study with buspirone. Br J Psychiatry 164:372379.

Cremers T.I., Giorgetti M., Bosker F.J., Hogg S., Arnt J., Mørk A., Honig G., Bøgesø K.P., Westerink B.H., den Boer H., Wikstrom H.V., Tecott L.H. (2004) Inactivation of 5-HT(2C) receptors potentiates consequences of serotonin reuptake blockade. Neuropsychopharmacology 29:1782-1789.

Dremencov E., Weizmann Y., Kinor N., Gispan-Herman I., Yadid G. (2006) Modulation of dopamine transmission by $5-\mathrm{HT}_{2 \mathrm{C}}$ and $5-\mathrm{HT}_{3}$ receptors: a role in the antidepressant response. Curr Drug Targets 7:165-175.

Gibaldi M., Perrier D. (1975) The trapezoid rule. In: Pharmacokinetics (Gibaldi M, Perrier D, eds), pp 293-296. New York: Marcel Dekker. 
Gould G.G., Altamirano A.V., Javors M.A., Frazer A. (2006) A comparison of the chronic treatment effects of venlafaxine and other antidepressants on serotonin and norepinephrine transporters. Biol Psychiatry 59:408-414.

Guilloux J.P., David D.J., Guiard B.P., Chenu F., Repérant C., Toth M., Bourin M., Gardier A.M. (2006) Blockade of 5-HT $\mathrm{HA}_{1 \mathrm{~A}}$ receptors by (+/-)-pindolol potentiates cortical 5-HT outflow, but not antidepressant-like activity of paroxetine: microdialysis and behavioural approaches in 5-HT $1 \mathrm{~A}$ receptor knockout mice. Neuropsychopharmacology 31:2162-2172.

Hajós M., Hajós-Korcsok E., Sharp T. (1999) Role of the medial prefrontal cortex in 5$\mathrm{HT}_{1 \mathrm{~A}}$ receptor-induced inhibition of 5-HT neuronal activity in the rat. Br J Pharmacol 126:1741-1750.

He M., Sibille E., Benjamin D., Toth M., Shippenberg T. (2001) Differential effects of $5-\mathrm{HT}_{1 \mathrm{~A}}$ receptor deletion upon basal and fluoxetine-evoked 5-HT concentrations as revealed by in vivo microdialysis. Brain Res 902:11-17.

Heisler L.K., Pronchuk N., Nonogaki K., Zhou L., Raber J., Tung L., Yeo G.S., O'Rahilly S., Colmers W.F., Elmquist J.K., Tecott L.H. (2007) Serotonin activates the hypothalamic-pituitary-adrenal axis via serotonin $2 \mathrm{C}$ receptor stimulation. $J$ Neurosci 27:6956-6964.

Hill M.N., Gorzalka B.B. (2005) Is there a role for the endocannabinoid system in the etiology and treatment of melancholic depression? Behav Pharmacol 16:333-352. Lanfumey L., Pardon M.C., Laaris N., Joubert C., Hanoun N., Hamon M., CohenSalmon C. (1999) 5- $\mathrm{HT}_{1 \mathrm{~A}}$ autoreceptor desensitization by chronic ultramild stress in mice. Neuroreport 10:3369-3374. 
Lanfumey L., Mannoury la Cour C., Froger N., Hamon M. (2000) 5-HT-HPA interactions in two models of transgenic mice relevant to major depression. Neurochem Res 25:1199-1206.

Le Poul E., Boni C., Hanoun N., Laporte A.M., Laaris N., Chauveau J., Hamon M., Lanfumey L. (2000) Differential adaptation of brain 5- $\mathrm{HT}_{1 \mathrm{~A}}$ and $5-\mathrm{HT}_{1 \mathrm{~B}}$ receptors and 5-HT transporter in rats treated chronically with fluoxetine. Neuropharmacology 39:110-122.

Ledent C., Valverde O., Cossu G., Petitet F., Aubert J.F., Beslot F., Bohme G.A., Imperato A., Pedrazzini T., Roques B.P., Vassart G., Fratta W., Parmentier M. (1999) Unresponsiveness to cannabinoids and reduced addictive effects of opiates in $\mathrm{CB}_{1}$ receptor knockout mice. Science 283:401-404.

Lesch K.P., Mayer S., Disselkamp-Tietze J., Hoh A., Schoellnhammer G., Schulte H.M. (1990) Subsensitivity of the 5-hydroxytryptamine1A (5- $\left.\mathrm{HT}_{1 \mathrm{~A}}\right)$ receptor-mediated hypothermic response to ipsapirone in unipolar depression. Life Sci 46:1271-1277.

Lesch K.P., Mössner R. (2006) Inactivation of 5-HT transport in mice: modeling altered 5-HT homeostasis implicated in emotional dysfunction, affective disorders, and somatic syndromes. Handb Exp Pharmacol 175:417-456.

Lowry O.H., Rosebrough N.J., Farr A.L., Randall R.J. (1951) Protein measurement with the Folin phenol reagent. J Biol Chem 193:265-275.

Maldonado R., Valverde O., Berrendero F. (2006) Involvement of the endocannabinoid system in drug addiction. Trends Neurosci 29:225-232.

Mangieri R.A., Piomelli D. (2007) Enhancement of endocannabinoid signaling and the pharmacotherapy of depression. Pharmacol Res 56:360-366.

Marsicano G., Wotjak C.T., Azad S.C., Bisogno T., Rammes G., Cascio M.G., Hermann H., Tang J., Hofmann C., Zieglgänsberger W., Di Marzo V., Lutz B. (2002) 
The endogenous cannabinoid system controls extinction of aversive memories. Nature 418:530-534

Martín M., Ledent C., Parmentier M., Maldonado R., Valverde O. (2002) Involvement of $\mathrm{CB}_{1}$ cannabinoid receptors in emotional behavior. Psychopharmacology (Berl) 159: 379-387.

Mato S., Aso E., Castro E., Martín M., Valverde O., Maldonado R., Pazos A. (2007) $\mathrm{CB}_{1}$ knockout mice display impaired functionality of $5-\mathrm{HT}_{1 \mathrm{~A}}$ and $5-\mathrm{HT}_{2 \mathrm{~A} / \mathrm{C}}$ receptors. $J$ Neurochem 103:2111-2120.

Moreira F.A., Lutz B. (2008) The endocannabinoid system: emotion, learning and addiction. Addict Biol 13:196-212.

Nichols D.E., Nichols C.D. (2008) Serotonin receptors. Chem Rev 108:1614-1641.

Nutt D.J. (2002) The neuropharmacology of serotonin and noradrenaline in depression. Int Clin Psychopharmacol 17:S1-12.

Olivier J.D., Van Der Hart M.G., Van Swelm R.P., Dederen P.J., Homberg J.R., Cremers T., Deen P.M., Cuppen E., Cools A.R., Ellenbroek B.A. (2008) A study in male and female 5-HT transporter knockout rats: an animal model for anxiety and depression disorders. Neuroscience 152:573-584.

Parrish J.C., Nichols D.E. (2006) Serotonin 5-HT(2A) receptor activation induces 2arachidonoylglycerol release through a phospholipase c-dependent mechanism. $J$ Neurochem 99:1164-1175.

Paxinos, G., Franklin, K.B.J. (1997) The Mouse Brain in Stereotaxic Coordinates Academic Press, San Diego.

Sanchís-Segura C., Cline B.H., Marsicano G., Lutz B., Spanagel R. (2004) Reduced sensitivity to reward in $\mathrm{CB}_{1}$ knockout mice. Psychopharmacology (Berl) 176:223-232. 
Serrats J., Mengod G., Cortés R. (2005) Expression of serotonin 5-HT2C receptors in GABAergic cells of the anterior raphe nuclei. J Chem Neuroanat 29:83-91.

Sharp T., Boothman L., Raley J., Quérée P. (2007) Important messages in the 'post': recent discoveries in 5-HT neuron feedback control. Trends Pharmacol Sci 28:629-636. Shippenberg T.S., He M., Chefer V. (1999) The use of microdialysis in the mouse: conventional versus quantitative techniques. Psychopharmacology (Berl) 147:33-34.

Steiner M.A., Wanisch K., Monory K., Marsicano G., Borroni E., Bächli H., Holsboer F., Lutz B., Wotjak C.T. (2008) Impaired cannabinoid receptor type 1 signaling interferes with stress-coping behavior in mice. Pharmacogenomics J 8:196-208.

Szabo B., Schlicker E. (2005) Effects of cannabinoids on neurotransmission. Handb Exp Pharmacol 168:327-65.

Trigo J.M., Renoir T., Lanfumey L., Hamon M., Lesch K.P., Robledo P., Maldonado R. (2007) 3,4-methylenedioxymethamphetamine self-administration is abolished in serotonin transporter knockout mice. Biol Psychiatry 62:669-679.

Tzavara E.T., Davis R.J., Perry K.W., Li X., Salhoff C., Bymaster F.P., Witkin J.M., Nomikos G.G. (2003) The $\mathrm{CB}_{1}$ receptor antagonist SR141716A selectively increases monoaminergic neurotransmission in the medial prefrontal cortex: implications for therapeutic actions. Br J Pharmacol 138:544-553.

Valverde O. (2005) Participation of the cannabinoid system in the regulation of emotional-like behavior. Curr Pharm Des 11:3421-3429.

Vandermaelen C.P., Aghajanian G.K. (1983) Electrophysiological and pharmacological characterization of serotonergic dorsal raphe neurons recorded extracellularly and intracellularly in rat brain slices. Brain Res 289:109-119. 
Figure 1. In vivo microdialysis experiments in the $\mathrm{PFC}$ of $\mathrm{CB}_{1}$ knockout mice. (A) Increased basal 5-HT extracellular levels in the PFC of $\mathrm{CB}_{1}$ knockout (filled bar) compared to wild-type (open bar) mice $(n=26)$. (B) Decreased percentage of increase of the 5-HT extracellular levels in the $\mathrm{CB}_{1}$ knockout mice (filled squares) respect to the wild-type littermates (open squares) after the fluoxetine administration $(\mathrm{n}=8-10)$. (C) AUC values for the percentage of increase of the 5-HT concentration in dialysates after fluoxetine or saline administration in $\mathrm{CB}_{1}$ knockout (filled bars) and wild-type (open bars) mice respect to basal values. Data are expressed as mean \pm SEM. $\star \mathrm{p}<0.05, \star \star \mathrm{p}$ $<0.01$ comparison between genotypes; 论抎柁 $\mathrm{p}<0.001$, when compared with the saline group of the same genotype (one-way ANOVA). Significant comparisons between the fluoxetine-treated (squares) and the saline-treated (triangles) groups are not included in order to clarify the figure.

Figure 2. 5-HTT quantification by $\left[{ }^{3} \mathrm{H}\right]$ Citalopram binding onto brain membranes revealed decreased 5-HTT levels in the frontal cortex and hippocampus of $\mathrm{CB}_{1}$ knockout (filled bar) compared to wild-type (open bar) mice at basal conditions. Data are expressed as mean $\pm \operatorname{SEM}(\mathrm{n}=10-11) . \star \mathrm{p}<0.05, \star \star \star \mathrm{p}<0.001$ compared to wild-type mice (one-way ANOVA).

Figure 3. Effect of ipsapirone on the firing of DRN 5-HT neurons in $\mathrm{CB}_{1}$ mutants compared with wild-type mice. (A) Integrated firing rate histograms (in spikes per 10 sec) show the effect of increasing doses of the $5-\mathrm{HT}_{1 \mathrm{~A}}$ receptor agonist ipsapirone on the electrical activity of a DRN 5-HT neuron in a control animal (upper) compared with a $\mathrm{CB}_{1}$ mutant (down). (B) Dose-response curves of ipsapirone-induced inhibition of the firing of DRN 5-HT neurons in brainstem slices from $\mathrm{CB}_{1}$ knockout compared with 
wild-type mice. Ipsapirone-induced inhibition is expressed as percentage of the baseline firing rate. Each point is the mean \pm SEM of data obtained from $15-21$ individual cells. The dotted lines illustrate the $\mathrm{EC}_{50}$ values of ipsapirone (abscissa) in $\mathrm{CB}_{1}$ mutants and wild-type mice. $\star \mathrm{p}<0.05$ as compared with the respective inhibition in wild-type mice.

Figure 4. Effect of ipsapirone on the firing of DRN 5-HT neurons in CD1 mice chronically treated with rimonabant ( $3 \mathrm{mg} / \mathrm{kg} /$ day, 14 days) or vehicle. (A) Integrated firing rate histograms (in spikes per $10 \mathrm{sec}$ ) show the effect of increasing doses of the 5$\mathrm{HT}_{1 \mathrm{~A}}$ receptor agonist ipsapirone on the electrical activity of a DRN 5-HT neuron in a vehicle treated (upper) compared with a rimonabant chronically treated animal (down). (B) Dose-response curves of ipsapirone-induced inhibition of the firing of DRN 5-HT neurons in brainstem slices from rimonabant chronically treated animals compared with vehicle treated mice. Ipsapirone-induced inhibition is expressed as percentage of the baseline firing rate. Each point is the mean \pm SEM of data obtained from 13-16 individual cells. The dotted lines illustrate the $\mathrm{EC}_{50}$ values of ipsapirone (abscissa) in rimonabant chronically treated animals and vehicle treated mice. $\star \star \star p<0.001$ as compared with the respective inhibition in wild-type mice.

Figure 5. In situ hybridization of $5-\mathrm{HT}_{2} \mathrm{C}$ receptor in $\mathrm{CB}_{1}$ knockout mice. (A) Representative images of mRNA encoding $5-\mathrm{HT}_{2 \mathrm{C}}$ in different coronal levels of wildtype (A1 to A5) and $\mathrm{CB}_{1}$ knockout mice (B1 to B5). (B) Quantification of the optical density in each brain area examined. $\mathrm{CB}_{1}$ knockout mice (filled bars) exhibited decreased $5-\mathrm{HT}_{2 \mathrm{C}}$ receptor expression in almost all the brain areas studied, excepting the CA3 area of the ventral hippocampus in which a significant increase was observed. Data are expressed as mean $\pm \operatorname{SEM}(n=5-6) . \star p<0.05, \star \star p<0.01, \star \star \star p<0.001$ 
compared to wild-type mice (one-way ANOVA). PFC, prefrontal cortex; NAcc, nucleus accumbens; $C P u$, caudate-putamen nucleus; Pir, piriform cortex; PVN, paraventricular nucleus of the hypothalamus; Amy, lateral amygdala; RSG, retrosplenial granular cortex; $C h P$, choroid plexus; Hab, habenula; $C A 3, \mathrm{CA} 3$ area of the ventral hippocampus; $P A G$, periaqueductal gray; $D R$, dorsal raphe nuclei.

Figure 6. Schematic representation of the mechanisms involved in serotonergic feedback that are altered in the absence of $\mathrm{CB}_{1}$ receptor activity. A 5-HT projection from the DRN to the $\mathrm{PFC}$ is represented in wild-type mice (upper panel) and $\mathrm{CB}_{1}$ knockout mice (lower panel). 5-HT (red circles) is released by 5-HT neurons (in red) located in the DRN, binds to 5-HT post-synaptic receptors (in dark blue) and is selectively reuptaken by 5 -HTT (in light blue) located in 5 -HT terminals. $5-\mathrm{HT}_{1 \mathrm{~A}}$ autoreceptors (in light green) situated in the soma of 5-HT neurons are able to inhibit the 5-HT firing. In the $\mathrm{DRN}, \mathrm{CB}_{1}$ cannabinoid receptors (in purple) and $5-\mathrm{HT}_{2 \mathrm{C}}$ receptors (in orange) are supposed to be mainly located on GABAergic interneurons (in dark green). Activation of $\mathrm{CB}_{1}$ receptors in the DRN produces inhibition of GABA release, thus removing the inhibitory effect of these GABAergic cells on 5-HT neurons. In contrast, activation of $5-\mathrm{HT}_{2 \mathrm{C}}$ receptors induces $\mathrm{GABA}$ release, promoting the inhibitory effect of these GABAergic cells on 5-HT neurons. Thus, the balance between the activity of $5-\mathrm{HT}_{2 \mathrm{C}}$ and $\mathrm{CB}_{1}$ receptors could determine the net effect of the GABAergic modulation on 5-HT neurons. The absence of $\mathrm{CB}_{1}$ receptor activity (lower panel) alters different serotonergic components leading to increased 5-HT extracellular levels by decreasing the activity of the receptors that directly or indirectly produce an inhibitory effect on 5-HT neurons and reducing the 5-HT clearance of the synaptic cleft. Hence, $\mathrm{CB}_{1}$ knockout mice exhibited a significant desensitization of $5-\mathrm{HT}_{1 \mathrm{~A}}$ 
autoreceptor, decreased 5-HTT levels in the PFC and diminished expression of 5- $\mathrm{HT}_{2 \mathrm{C}}$ receptor in the DRN. 
A

B
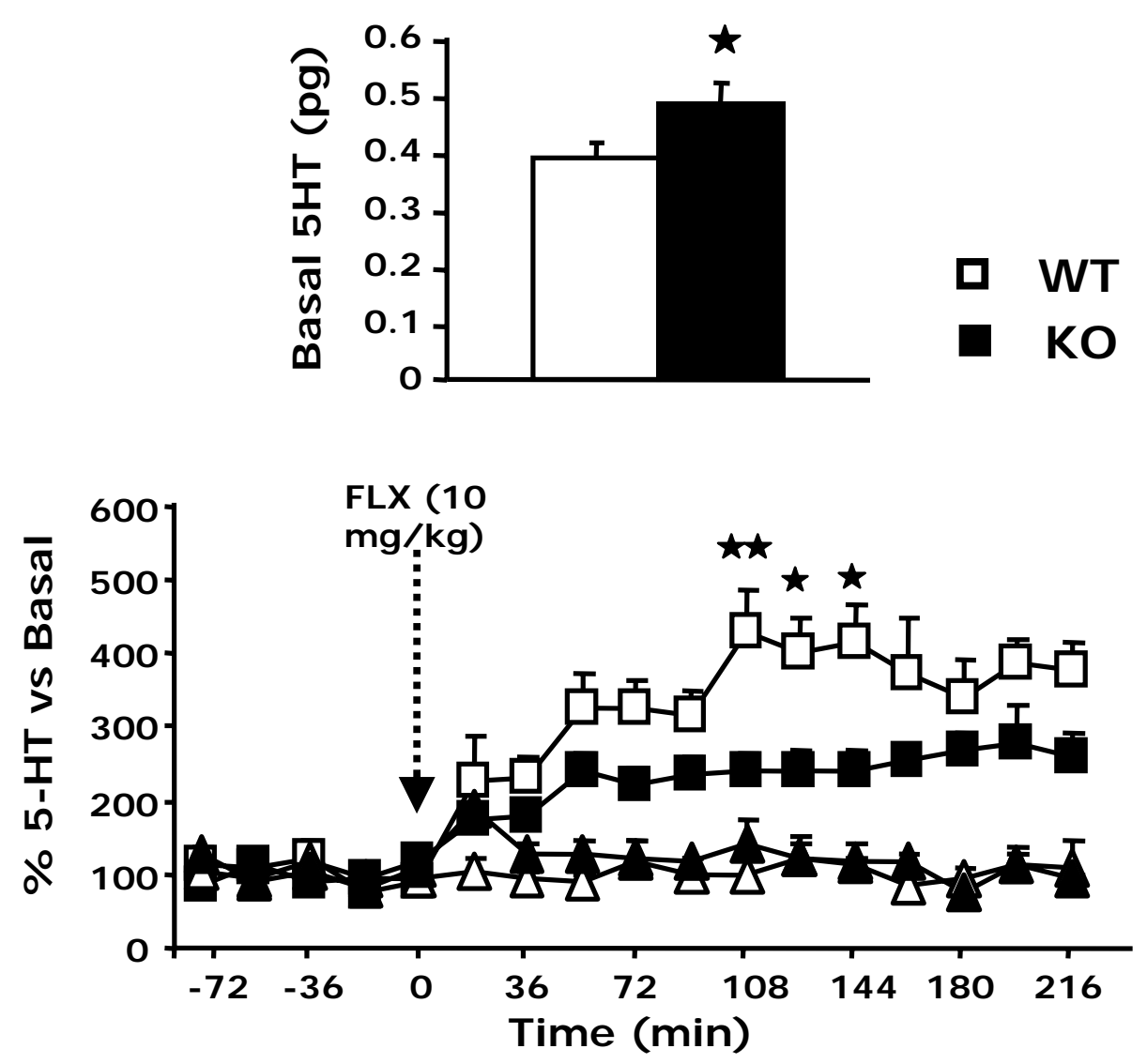

$-\Delta$ WT SAL $\neg$ KO SAL $\rightarrow-$ WT FLX $\rightarrow-$ KO FLX

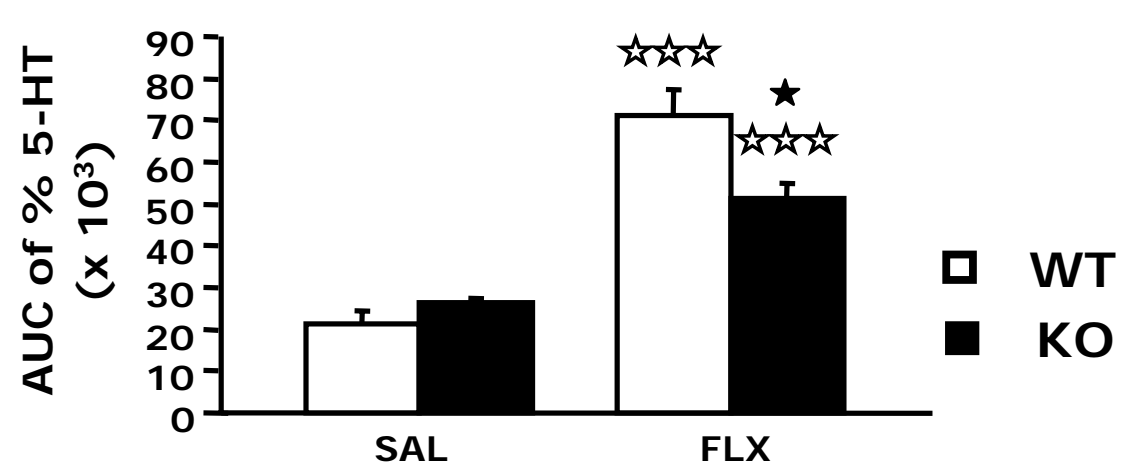




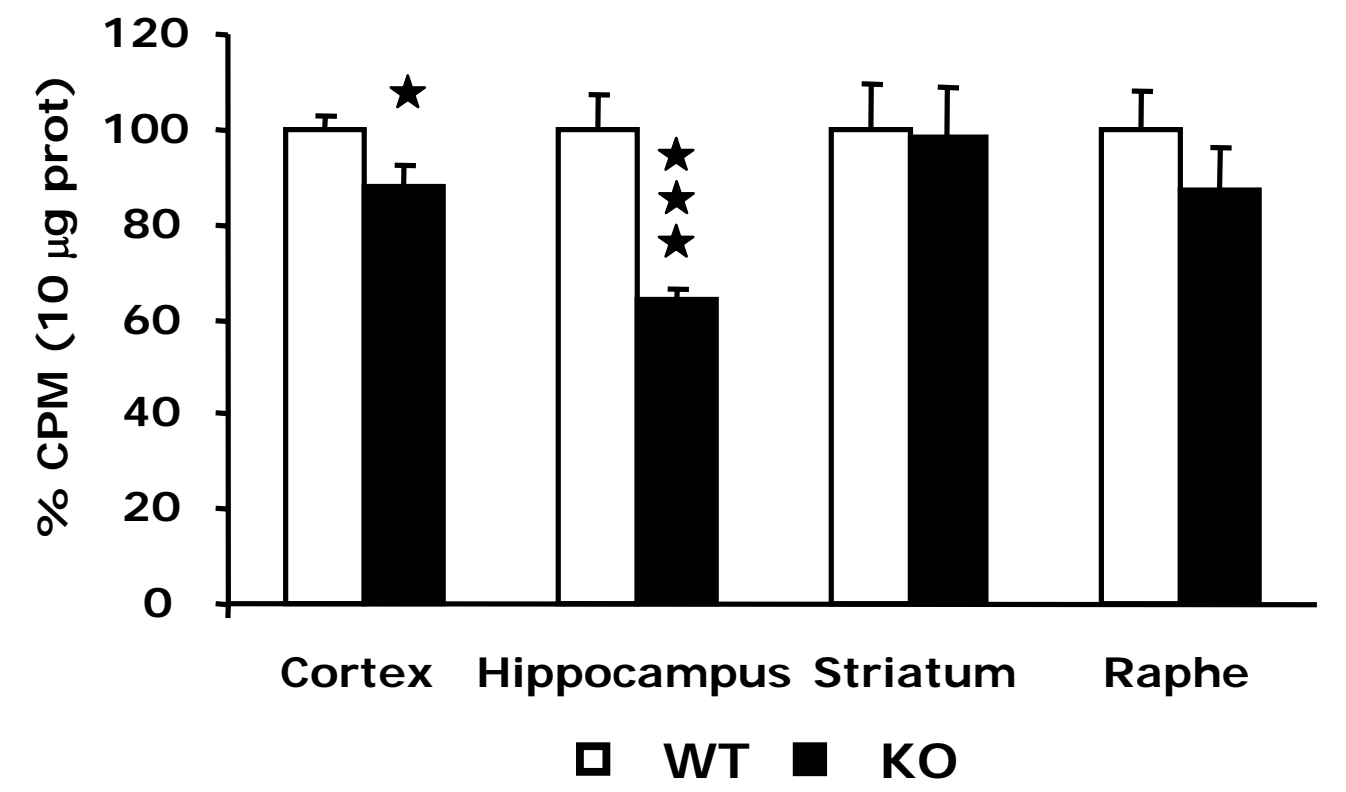

Fig 2 Aso et al 
A

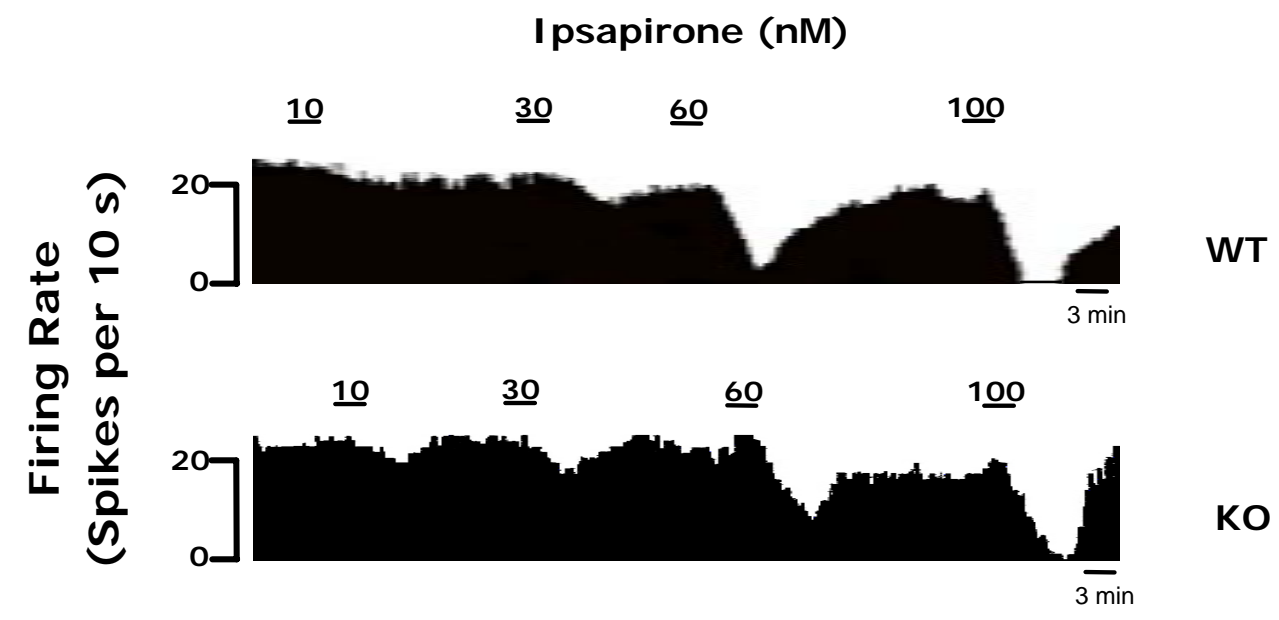

B

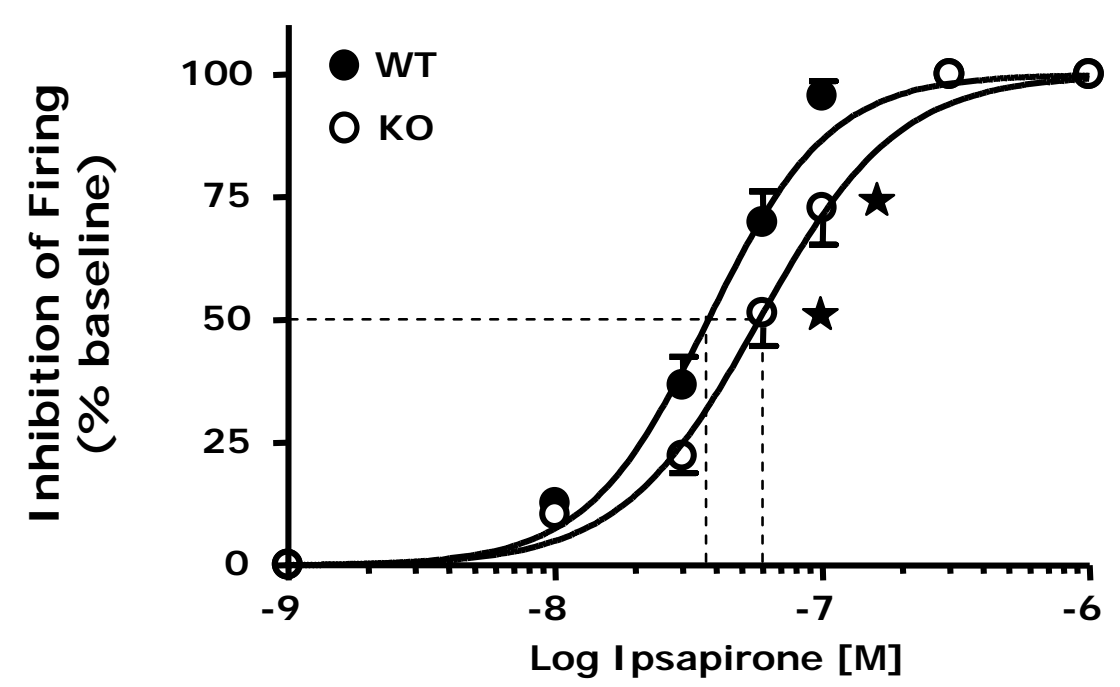

Fig 3 Aso et al 
A

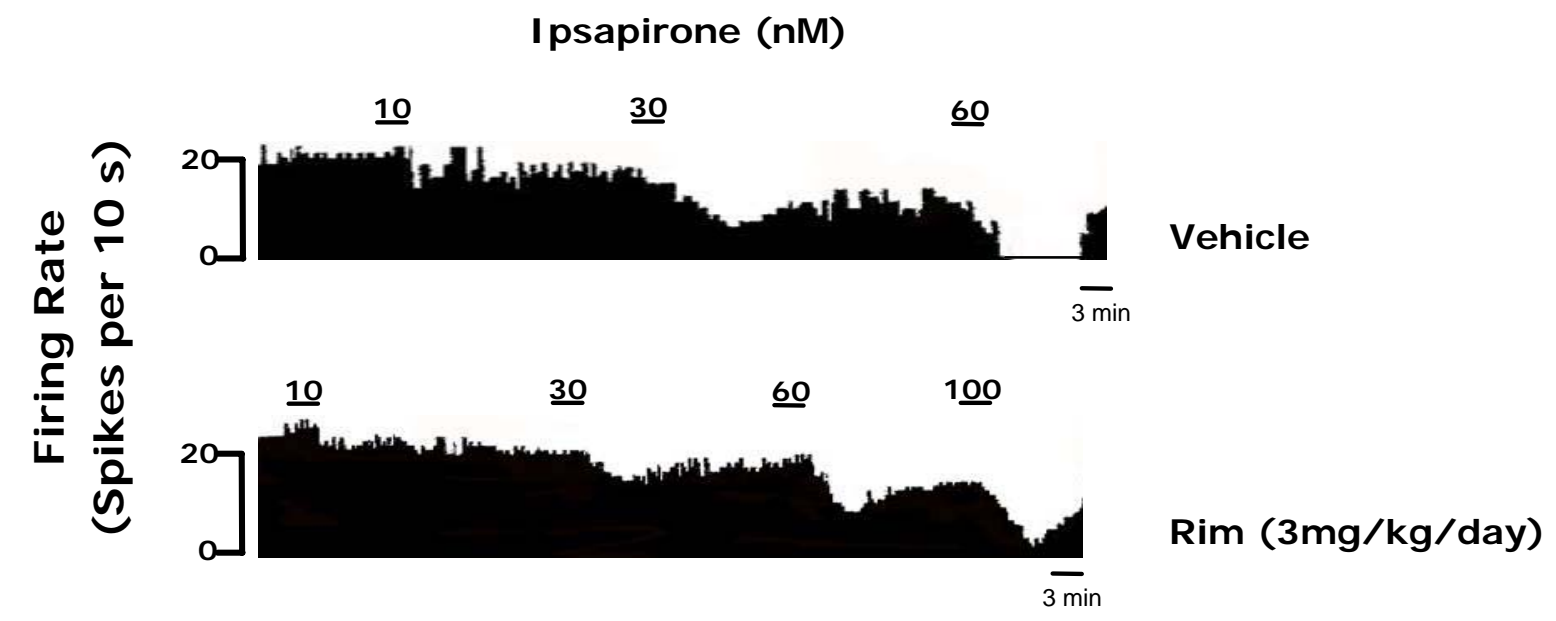

B

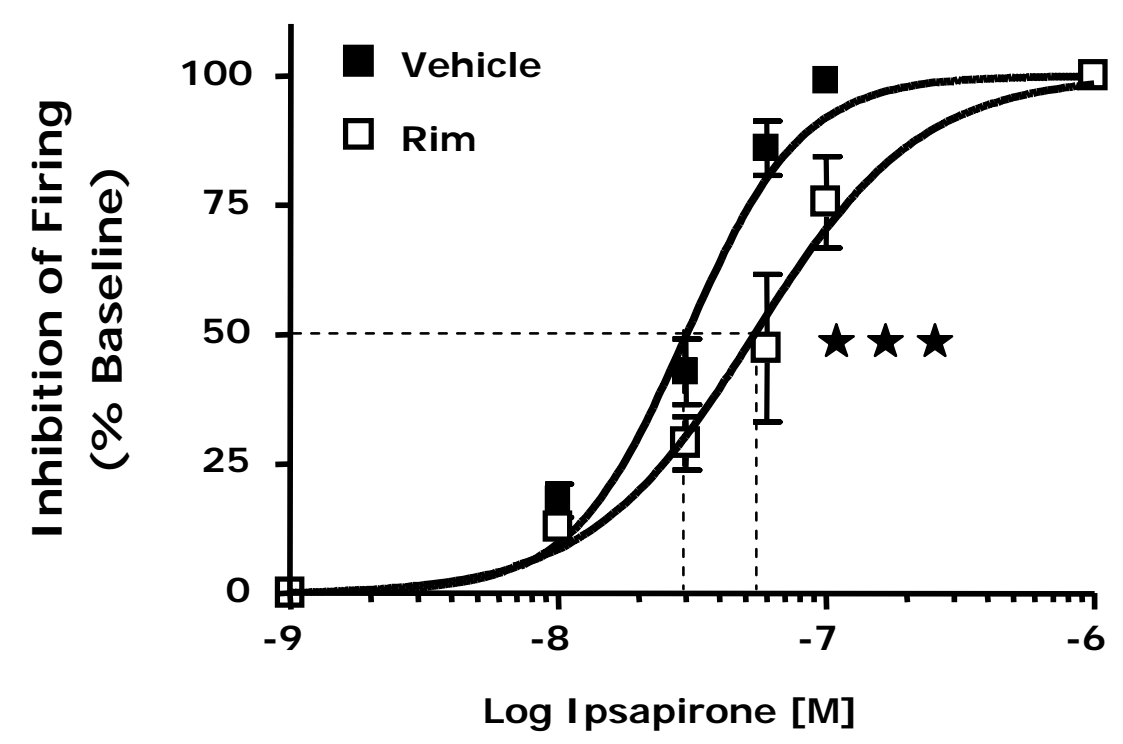

Fig 4 Aso et al 


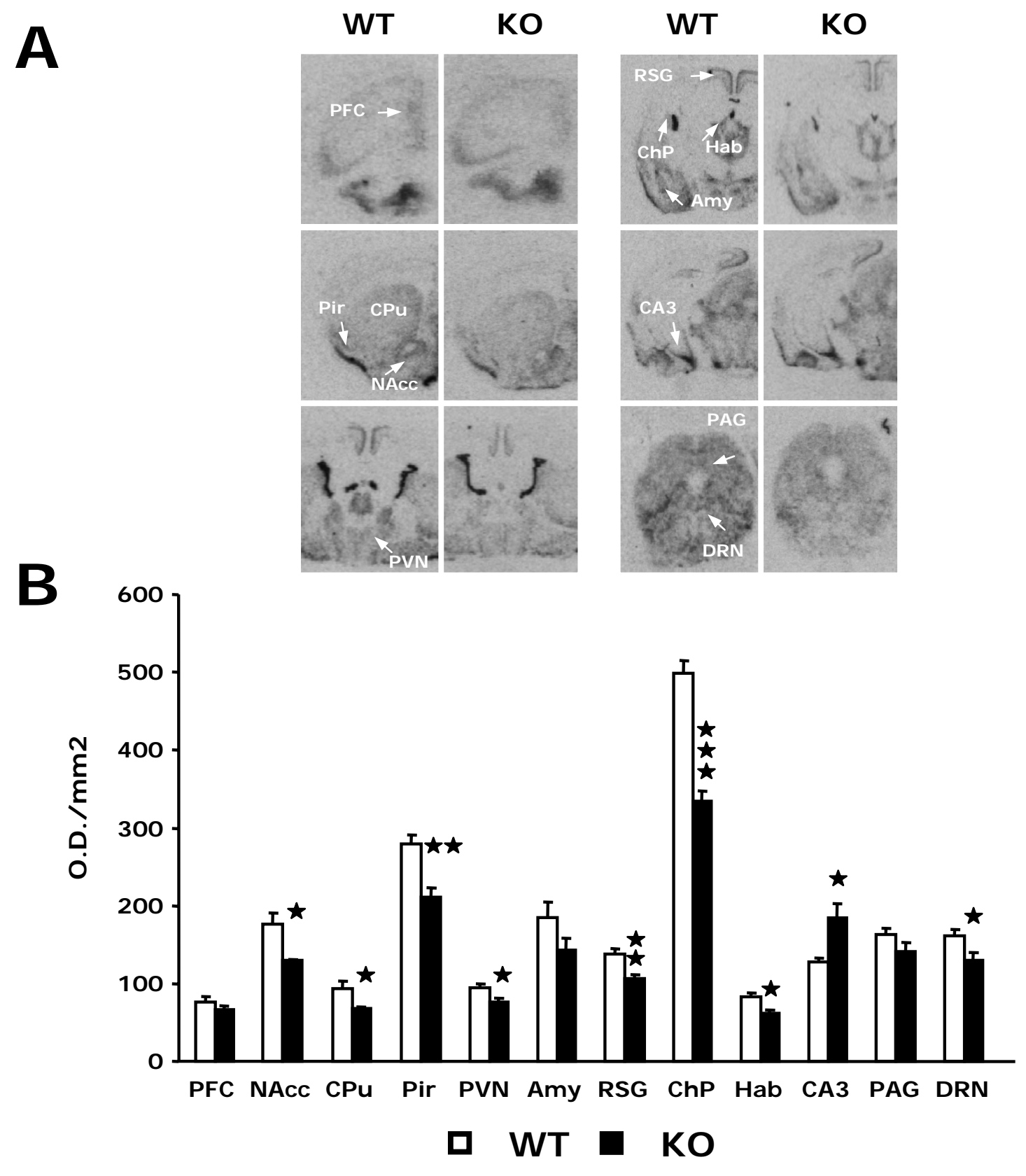

Fig 5 Aso et al 


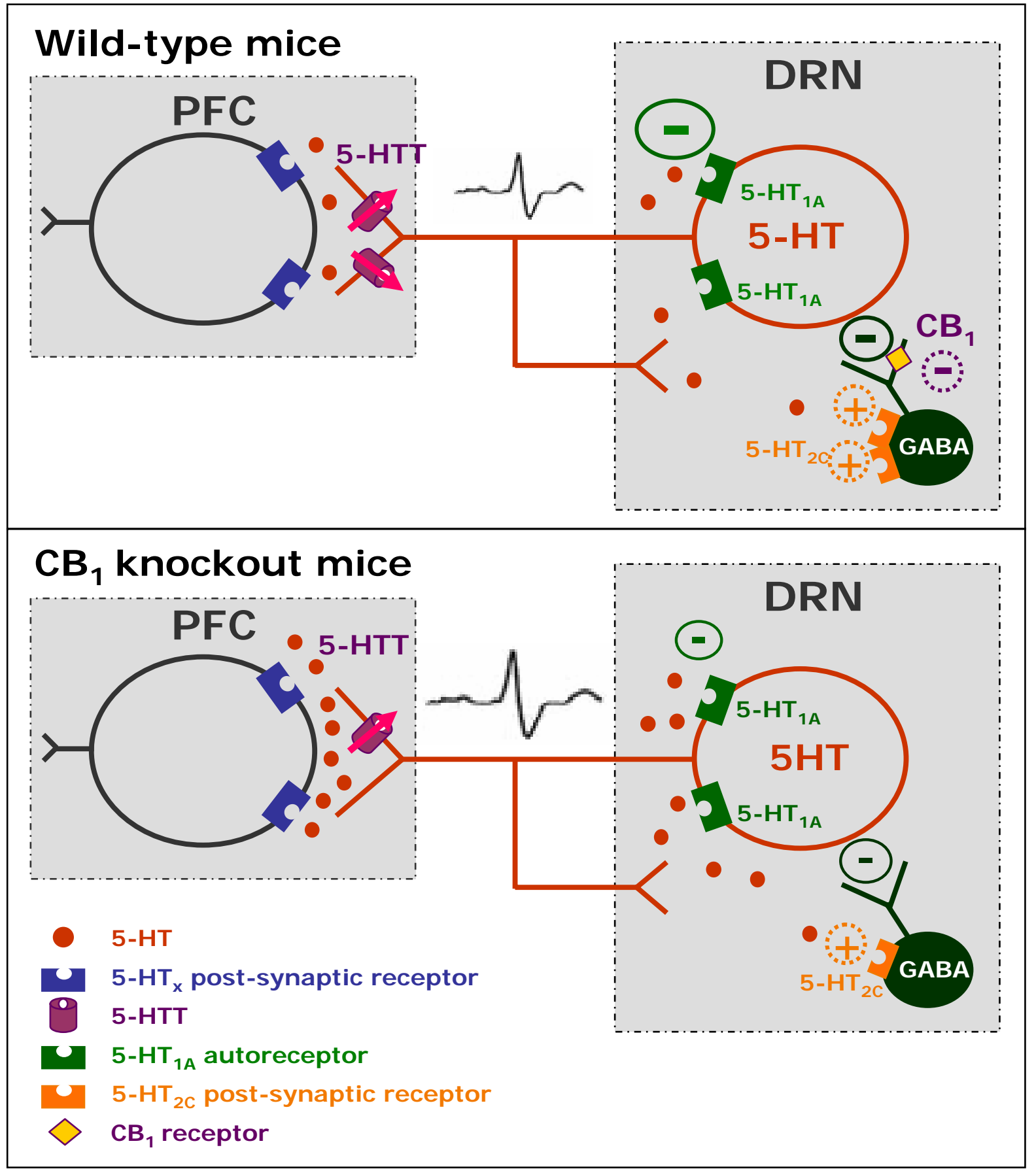

